\title{
Physico-chemical properties and chromatographic findings of different natural solvent extracts of Vitex negundo Linn.
}

\author{
Research Article
}

\author{
Vivek Kumar ${ }^{\text {* }}$, Harmeet Kaur ${ }^{2}$, Galib $^{3}$, Prajapati PK ${ }^{4}$ \\ 1. PhD (M Pharma) Scholar, 2. PhD (Ayu) Scholar, 3. Assistant Professor, 4. Professor \\ Dept. of Rasa Shastra \& Bhaishajya Kalpana, \\ Institute for Post Graduate Teaching and Research in Ayurveda, \\ Gujarat Ayurved University, Jamnagar, 361 008, Gujarat
}

\begin{abstract}
Introduction: Ayurveda, uses various herbs that are converted into different dosage forms mostly in presence of Jala (water) as solvent. In addition to water; seers also advocated certain other solvents for extraction of active principles from the herbs. Works on using traditional solvents other than water in extracting principles from different herbs are not reported till date. Aims: Considering lack of such evidences, an attempt has been made to prepare Nirgundi Ghana (solid extract of Vitex negundo Linn.) in three different solvents i.e. Jala (water), Kanji (sour gruel) and Gomutra (cow's urine) and analyze respective physico-chemical profiles. Materials and Methods: Ghana was prepared by classical methods described in Ayurveda. The samples were analyzed through relevant physico-chemical parameters. Results: In pharmaceutical study; yield was found more in presence of Kanji and Gomutra. Physico-chemical profiles showed few differences, but in most of the cases, they were insignificant. Conclusion: Based on preliminary physico-chemical profiles, it cannot be ascertained the usefulness of the finished products in therapeutics. Relevant experimental studies to identify and characterize the active phytoconstituents and evaluate therapeutic utilities of the principles extracted into the respective solvents are essential in further studies.
\end{abstract}

Keywords: Extraction, Ghana, Gomutra, Kanji, Nirgundi, Vitex negundo

\section{Introduction:}

Ayurveda emphasizes on maintenance, promotion of health and curing diseases through natural resources in a comprehensive way.(1) As these resources cannot be used in their natural forms, are converted into different dosage forms mostly in presence of Jala (water) as the drava dravya (extracting media / solvent).

It is evident from preliminary screening through the classics that, seers used other dravas (liquid medias) like Ksira (milk),(2) Go-mutra (cow's urine), (3) Takra (butter milk), (4) Kanji (sour gruel),(5) and Ksarodaka (alkaline water)(6) etc. in addition to Jala in different pharmaceutical procedures based on necessity. This infers that, seers have knowledge about rate and transfer of medicinal properties of any dravya (drug) on the virtue of drava dravya. As some of these solvents are alkaline and some are acidic, it is to be investigated and determined the ideal extracting media for various herbs on scientific basis. Published information on such kind of

\footnotetext{
*Corresponding Author:

Vivek kumar

PhD (M Pharma) Scholar,

Dept. of Rasa Shastra \& Bhaishajya Kalpana

IPGT\&RA, Gujarat Ayurved University,

Jamnagar -361008.

Mobile No.: 09979878245

E-mail: dr.anjanagoswami@yahoo.com
}

studies are not found till date and is expected to revolutionize the methods of preparations to bring out more effective preparations than those of prepared by conventional methods.

Considering this, it is planned to prepare Nirgundi Ghana (solid extract of Vitex negundo Linn.) in presence of three different medias (Jala, Kanji and Gomutra) and analyze preliminary physico-chemical profiles. Nirgundi (Vitex negundo Linn.) is selected in the present study, as the plant is abundantly, easily available and frequently used in different ailments by Ayurvedic physicians and folklore healers as well.

\section{Materials and Methods: \\ Procurement of raw material:}

Fresh leaves of Nirgundi were collected from botanical garden of Gujarat Ayurved University, Jamnagar and authenticated at Pharmacognosy laboratory. Kanji was prepared in the laboratory of Rasashastra \& Bhaishajya kalpana, IPGT \& RA, GAU, Jamnagar by following standard methods of preparation. (7) Gomutra was procured from local Goshala (cow-shed), Jamnagar.

\section{Preparation of test formulations:}

Ghana was prepared from fresh leaves of Nirgundi that were crushed thoroughly and mixed with required amounts ( 8 parts) of potable water.(8) The contents were subjected to mild heat maintaining temperature in between $95-100^{\circ} \mathrm{C}$. The contents were 
stirred constantly, in order to avoid possibilities of settling down of the contents and their charring. When the volume was reduced to one quarter; the contents were filtered through a clean cotton cloth into a stainless steel container to obtain Kwatha (decoction). The decoction was further subjected to the process of punah paka (re-boiling) with continuous stirring till the contents become semi-solid, were shifted into stainless steel tray and subjected to drying maintaining temperature around $50^{\circ} \mathrm{C}$. The dried aqueous extract (W) was collected carefully with the help of scraper and used in the study. Similar procedure was repeated in presence of Kanji and Gomutra as solvents to obtain solid extracts that were labeled as $\mathrm{K}$ and $\mathrm{G}$ respectively. In addition to these practicals; attempts were also made to extract Ghana of Gomutra and Kanji individually to calculate the possible extract of solvents that enter into the finished product (W, K and $\mathrm{G})$.

\section{Analytical Study}

All the samples of Nirgundi Ghana (W, K, and G) were analysed to evaluate organoleptic characters, preliminary physico-chemical analysis (including estimation of $\mathrm{pH},(9)$ Total ash,(10) Acid insoluble ash, (11) Water Soluble Extractive,(12) Alcohol Soluble Extractive, Loss on Drying at $105^{0} \mathrm{C}$ ), qualitative estimation of functional groups.(13)

\section{HPTLC Profile}

Ethyl Acetate: Methanol: Water: Glacial Acetic Acid (7.8:1.2:0.7:0.3) was selected as solvent system and Vaniline Sulphuric Acid as spray reagent. All tracks of Ghana (W, K, and G) were scanned under $254 \mathrm{~nm}$ and $366 \mathrm{~nm}$ and $\mathrm{Rf}$ values are recorded accordingly.

\section{HPTLC condition}

Application mode

Development chamber : CAMAG Linomat V Hamilton Syringe CAMAG Twin trough chamber $(20 \times 10 \mathrm{~cm})$

Plates Precoated silica gel $\mathrm{GF}_{254}$ plates

Chamber saturation Development time Scanner

Scanning mode

Detection

Photo documentation Data system

Drying device U.V. Spectrum

$30 \mathrm{~min}$

$30 \mathrm{~min}$

CAMAG Scanner III

Linear at $254 \mathrm{~nm}$ and $366 \mathrm{~nm}$

Deutarium lamp, Mercury lamp

CAMAG reprostar

WINCATS software

(Ver. 3.17)

Oven

$200 \mathrm{~nm}$ to $700 \mathrm{~nm}$

\section{Results}

Brief details of Nirgundi Ghana obtained in presence of different solvents and details of Ghana obtained from individual solvents (Gomutra and Kanji) are placed at Table 1. Organoleptic characters (Table 2 ), comparative preliminary physico-chemical profiles (Table - 2), qualitative estimation of different functional groups (Table - 3), percentage of alkaloids (Table - 3 ),

observations of HPTLC study along with Rf values (Table - 4) of all the three samples are placed at respective tables. (Fig.-1)

\section{Discussion:}

Apart from certain organoleptic changes; no significant differences were observed during pharmaceuticals stages of Ghana preparation. It is evident from table-1 that, the quantity of extract of Nirgundi is more in Kanji and Gomutra than Jala. At the end of the preparation, it is found that Kanji yielded more percentage of Ghana (40.4\%) followed by Gomutra (34.5\%), and least in Jala (6.8\%). Kanji, being a media of amla pradhana is expected to liquefy (kledayati), disintegrate (jarayati), and possibly facilitate more extraction of principles (apakarshayati) from the raw material.(14) This may be the probable reason behind extraction of more percentage of Ghana in presence of Kanji as solvent. Similarly, with the other solvent Gomutra that is alkaline in nature.(15) Subtracting Ghana of respective solvents from the total yield infers that, the solvents other than water facilitate extraction of more principles into the end product.

Total Ash was high in case of sample G, followed by W, and K. Alcohol Soluble Extractive was very low in sample $\mathrm{K}$ and was almost equal in other two samples. Variations in other physico-chemical profiles are insignificant. Alkaloids, Tannins, Saponins, Phenols, and Flavanoids were found in all the three samples, while Glycosides, Protein, Quinines were absent in all the three samples. Sterols, and Triterpenoids were present in $\mathrm{W}$, and $\mathrm{G}$ amples (and absent in $\mathrm{K}$ ), and Carbohydrate was absent in G. Quantitatively, the percentage of alkaloids present in sample $\mathrm{K}$ was found to be lesser (0.19), in comparison to sample W (0.44), and sample $\mathrm{G}$ (1.09).

During the HPTLC study, spots in three samples were observed at different frequencies, few of them were appeared to be in the same frequencies. The three samples (W, K, and $\mathrm{G})$ revealed 14,13 , and 10 spots at $254 \mathrm{~nm}$; while 7, 8, and 4 spots at $366 \mathrm{~nm}$ respectively. After spray with Vanillin - Sulphuric acid, twelve spots in sample $\mathrm{W}$, and nine spots each in sample $\mathrm{K}$ and $\mathrm{G}$ were observed. These differences indicate the presence of variable functional groups in both the trial groups.

\section{Conclusion:}

References available in the classics reveal that, the seers of ancient India identified importance of different solvents other than jalam (water) in specific cases. Sushruta opines that, activity of substances increases by Arishta Dravya (solvents of alcoholic base) Samyoga.(16) Though, the yield is more in case of Kanji or Gomutra, it cannot be ascertained that, the extracted priciples are useful in therapeutics. Hence, relevant experimental studies are needed to justify comparative efficacies. In addition, identification and characterization of the phyto-constituents extracted through respective solvents is also essential.

These solvents might have been used by seers in selected cases to extract desired principles that may be useful in specific conditions. On the other hand, use of 
such solvents may extract specific active principles leaving behind many other principles from the drug, which possibly contribute a lot in the treatment. Whether using such solvents in Ayurvedic practice is useful or not, is questionable and there is a need to explore this issue.

\section{References:}

1) Acharya Y.T. Charaka Samhita, Sutra sthana $30 / 26,5^{\text {th }}$ Ed, Varanasi, Chaukamba Sanskrit Sansthan, 2001

2) Acharya J.T. Charaka Samhita, Chikitsa sthana $4 / 15,5^{\text {th }}$ Ed, Varanasi, Chaukamba Sanskrit Sansthan, 2001

3) Acharya J.T. Charaka Samhita, Chikitsa sthana 9/34, $5^{\text {th }}$ Ed, Varanasi, Chaukamba Sanskrit Sansthan, 2001

4) Acharya J.T. Charaka Samhita, Chikitsa Sthana $15 / 90,5^{\text {th }}$ Ed, Varanasi, Chaukamba Sanskrit Sansthan, 2001

5) Acharya J.T. Charaka Samhita, Chikitsa Sthana 9/54, $5^{\text {th }}$ Ed, Varanasi, Chaukamba Sanskrit Sansthan, 2001

6) Acharya J.T. Charaka Samhita, Chikitsa Sthana 1ii/7, $5^{\text {th }}$ Ed, Varanasi, Chaukamba Sanskrit Sansthan, 2001

7) Rasa Vagbhata, Rasa Ratna Samuccaya 11/29, commentary by Dattatreya Ananta Kulkarni, New
Delhi, Meharchand Lachhmandas; 2010

8) Sharangadhara, Sharangadhara Samhita, Madhyama Khanda 9/3, Gudartha Dipika Sanskrit Commentary by Kashiram Vaidya, $6^{\text {th }} \mathrm{Ed}$, Varanasi, Chaukamba Orientalia, 2005

9) Anonymous, The Ayurvedic Pharmacopoeia of India, Ministry of Health and Family Welfare, Govt. of India, Part - I, Vol. V, Appendix 2.2.1

10) Ibid, The Ayurvedic Pharmacopoeia of India, Part I, Vol. V, Appendix 2.2.2

11) Ibid, The Ayurvedic Pharmacopoeia of India, Part I, Vol. V, Appendix 2.2.9

12) Ibid, The Ayurvedic Pharmacopoeia of India, Part I, Vol. V, Appendix 2.2.3

13) Khandelwal KR. Practical Pharmacognosy techniques and experiments. $16^{\text {th }}$ Ed. Pune, Nirali Prakashan; 2006;149-56.

14) Acharya J.T. Charaka Samhita, Sutra sthana 26/43ii, $5^{\text {th }}$ Ed, Varanasi, Chaukamba Sanskrit Sansthan, 2001

15) Acharya J.T. Charaka Samhita, Sutra 26/43-iii, $5^{\text {th }}$ Ed, Varanasi, Chaukamba Sanskrit Sansthan, Varanasi, 2001

16) Acharya J.T. Sushruta Samhita, Sutra sthana 45/194, Reprint edition, Varanasi, Chaukhamba Surbharati Sansthan, 2008

Table 1: Average details of Ghana obtained in different batches.

\begin{tabular}{|c|c|c|c|c|c|c|c|}
\hline $\begin{array}{l}\text { Sl. } \\
\text { No. }\end{array}$ & Group & $\begin{array}{c}\text { Quantity of } \\
\text { Nirgundi }\end{array}$ & $\begin{array}{c}\text { Solvent } \\
\text { added }\end{array}$ & $\begin{array}{c}\text { Quantity } \\
\text { of Solvent }\end{array}$ & $\begin{array}{c}\text { Decoction } \\
\text { obtained }\end{array}$ & $\begin{array}{c}\text { Ghana } \\
\text { obtained (g) }\end{array}$ & $\begin{array}{c}\% \text { of Ghana } \\
\text { obtained }\end{array}$ \\
\hline 1 & $\bar{W}$ & $200 \mathrm{~g}$ & Jala & $1600 \mathrm{ml}$ & $400 \mathrm{ml}$ & 13.7 & 06.8 \\
\hline 2 & $\bar{K}$ & $200 \mathrm{~g}$ & Kanji & $1600 \mathrm{ml}$ & $400 \mathrm{ml}$ & 80.9 & 40.4 \\
\hline 3 & $\bar{G}$ & $200 \mathrm{~g}$ & Gomutra & $1600 \mathrm{ml}$ & $400 \mathrm{ml}$ & 68.1 & 34.5 \\
\hline $\begin{array}{r}\text { Sl. } \\
\text { No. }\end{array}$ & & $\begin{array}{c}\text { Quantity of } \\
\text { Media }\end{array}$ & Media & & & $\begin{array}{c}\text { Ghana } \\
\text { obtained (g) }\end{array}$ & $\begin{array}{c}\% \text { of Ghana } \\
\text { obtained }\end{array}$ \\
\hline 1 & & $100 \mathrm{ml}$ & Gomutra & & & 4.9 & 4.9 \\
\hline 2 & & $100 \mathrm{ml}$ & Kanji & & & 6.8 & 6.8 \\
\hline
\end{tabular}

Table 2: Organoleptic and Physico-chemical characters of Nirgundi Ghana of three samples

\begin{tabular}{|c|l|l|l|l|}
\hline \multirow{2}{*}{ Characters } & \multicolumn{3}{c|}{ K } & \multicolumn{1}{c|}{ G } \\
\cline { 3 - 5 } & \multirow{2}{*}{ W } & \multicolumn{2}{c|}{ Batch } \\
\hline $\mathbf{1}$ & Color & Brown & Brown & Brown \\
\hline $\mathbf{2}$ & Odor & Characteristic & Characteristic & Characteristic odor of urine \\
\hline $\mathbf{3}$ & Appearance & Dark & Dark & Dark \\
\hline $\mathbf{4}$ & Taste & Bitter & $\begin{array}{l}\text { Bitter with mild } \\
\text { acidic }\end{array}$ & Bitter with characteristic odor of urine \\
\hline $\mathbf{5}$ & $\mathbf{P}^{\mathrm{H}}(\mathbf{5 \%}$ Aqu. solution) & 6.69 & 6.73 & 6.75 \\
\hline $\mathbf{6}$ & Loss on drying at 105 $^{\mathbf{0}}$ & 4.96 & 4.22 & 4.71 \\
\hline $\mathbf{7}$ & Total ash & 10.22 & 5.58 & 44.21 \\
\hline $\mathbf{8}$ & Acid insoluble ash & 0.82 & 0.71 & 1.21 \\
\hline $\mathbf{9}$ & Water Soluble extractive & 83.68 & 90.02 & 84.74 \\
\hline $\mathbf{1 0}$ & Alcohol Soluble Extractive & 52.106 & 12.21 & 50.85 \\
\hline
\end{tabular}


Table 3: Qualitative estimation of different functional groups in Nirgundi Ghana

\begin{tabular}{|c|l|c|c|c|}
\hline \multicolumn{1}{|c|}{ Functional Group } & W & K & G \\
\hline $\mathbf{1}$ & Alkaloid & $+\mathrm{ve}$ & $+\mathrm{ve}$ & $+\mathrm{ve}$ \\
\hline $\mathbf{2}$ & Carbohydrate & $+\mathrm{ve}$ & $+\mathrm{ve}$ & $-\mathrm{ve}$ \\
\hline $\mathbf{3}$ & Tannin & $+\mathrm{ve}$ & $+\mathrm{ve}$ & $+\mathrm{ve}$ \\
\hline $\mathbf{4}$ & Saponin & $+\mathrm{ve}$ & $+\mathrm{ve}$ & $+\mathrm{ve}$ \\
\hline $\mathbf{5}$ & Glycosides & $-\mathrm{ve}$ & $-\mathrm{ve}$ & $-\mathrm{ve}$ \\
\hline $\mathbf{6}$ & Flavanoids & $+\mathrm{ve}$ & $+\mathrm{ve}$ & $+\mathrm{ve}$ \\
\hline $\mathbf{7}$ & Phenols & $+\mathrm{ve}$ & $+\mathrm{ve}$ & $+\mathrm{ve}$ \\
\hline $\mathbf{8}$ & Protein & $+\mathrm{ve}$ & $-\mathrm{ve}$ & $-\mathrm{ve}$ \\
\hline $\mathbf{9}$ & Sterols & $-\mathrm{ve}$ & $-\mathrm{ve}$ & $+\mathrm{ve}$ \\
\hline $\mathbf{1 0}$ & Quinines & $+\mathrm{ve}$ & $-\mathrm{ve}$ & $+\mathrm{ve}$ \\
\hline $\mathbf{1 1}$ & Triterpenoids & 0.44 & 0.19 & 1.09 \\
\hline
\end{tabular}

$+\mathrm{ve}=$ Present, $-\mathrm{ve}=$ Absent

Table 4: Rf values in Nirgundi Ghana (Before Spray)

\begin{tabular}{|c|c|c|c|}
\hline Track & Visualization & $\begin{array}{l}\text { No. of } \\
\text { spots }\end{array}$ & Rf Values \\
\hline \multirow{2}{*}{$\begin{array}{c}\text { Track } 1 \\
\text { (W) }\end{array}$} & $\lambda \operatorname{Max} 254 \mathrm{~nm}$ & 14 & $\begin{array}{l}0.02,0.07,0.10,0.14,0.21,0.27,0.33,0.39,0.52,0.63,0.69,0.74 \text {, } \\
0.86,0.99\end{array}$ \\
\hline & $\lambda \operatorname{Max} 366 \mathrm{~nm}$ & 7 & $0.02,0.09,0.24,0.36,0.45,0.48,0.64$ \\
\hline \multirow{2}{*}{$\begin{array}{c}\text { Track } 2 \\
(\mathbf{K})\end{array}$} & $\lambda \operatorname{Max} 254 \mathrm{~nm}$ & 13 & $\begin{array}{l}0.02,0.09,0.21,0.26,0.37,0.44,0.53,0.60,0.67,0.72,0.80,0.84 \text {, } \\
0.99\end{array}$ \\
\hline & $\lambda \operatorname{Max} 366 \mathrm{~nm}$ & 8 & $0.02,0.09,0.25,0.34,0.44,0.52,0.62,0.87$ \\
\hline \multirow{2}{*}{$\begin{array}{c}\text { Track } 3 \\
\text { (G) }\end{array}$} & $\lambda \operatorname{Max} 254 \mathrm{~nm}$ & 10 & $0.03,0.11,0.27,0.37,0.38,0.50,0.61,0.72,0.81,0.99$ \\
\hline & $\lambda \operatorname{Max} 366 \mathrm{~nm}$ & 4 & $0.03,0.14,0.39,0.98$ \\
\hline \multicolumn{4}{|c|}{ Rf values in Nirgundi Ghana (After Spray) } \\
\hline \multicolumn{2}{|c|}{ Track $1(W)$} & 12 & $0.02,0.06,0.15,0.20,0.31,0.37,0.43,0.59,0.65,0.71,0.82,0.95$ \\
\hline \multicolumn{2}{|c|}{ Track $2(\mathbf{K})$} & 9 & $0.02,0.06,0.14,0.23,0.35,0.50,0.57,0.63,0.69$ \\
\hline \multicolumn{2}{|c|}{ Track 3 (G) } & 9 & $0.04,0.11,0.22,0.34,0.40,0.51,0.59,0.70,0.95$ \\
\hline
\end{tabular}




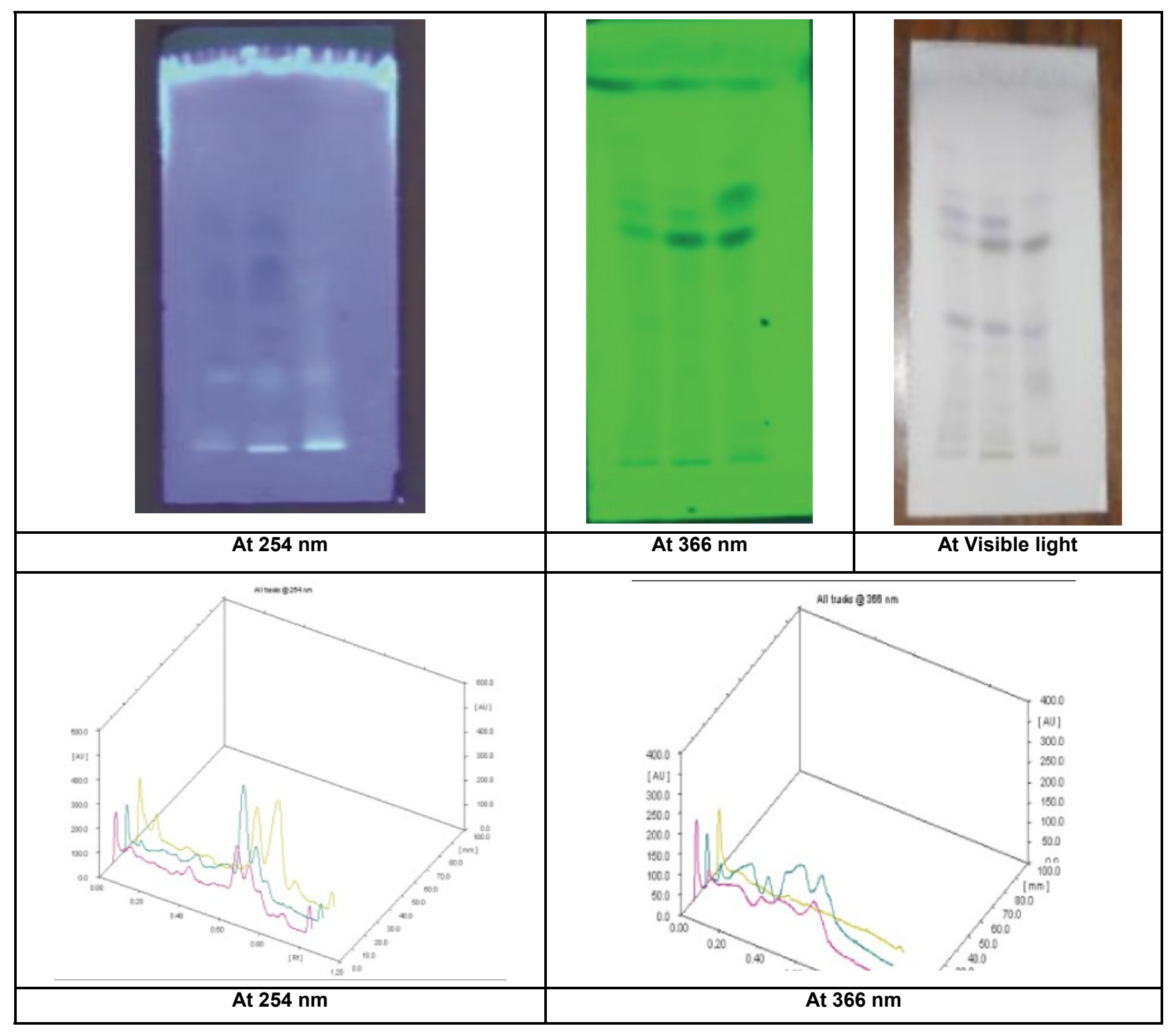

Fig.1: HPTLC of WKG 